\title{
Efficient Electrochemical Removal of Ammonia with Various Cathodes and $\mathrm{Ti} / \mathrm{RuO}_{2}$-Pt Anode
}

\author{
Yaning Wang, Xu Guo, Jinglu Li, Yingnan Yang, Zhongfang Lei, Zhenya Zhang* \\ Graduate School of Life and Environmental Sciences, University of Tsukuba, Tsukuba, Japan \\ Email: "zhang.zhenya.fu@u.tsukuba.ac.jp
}

Received August 31, 2012; revised September 30, 2012; accepted October 12, 2012

\begin{abstract}
Electrochemical oxidation of ammonia was studied with an objective to enhance the selectivity of ammonia to nitrogen gas and to remove the by-products in an undivided electrochemical cell, in which various cathodes and $\mathrm{Ti} / \mathrm{RuO}_{2}-\mathrm{Pt}$ anode were assembled. In the present study, anodic oxidation of ammonia and cathodic reduction of by-products were achieved, especially with $\mathrm{Cu} / \mathrm{Zn}$ as cathode. In the presence of $1.0 \mathrm{~g} / \mathrm{L} \mathrm{NaCl}$ the ammonia- $\mathrm{N}$ decreased from 100.0 to 0 after $120 \mathrm{~min}$ electrolysis at current density of $30 \mathrm{~mA} / \mathrm{cm}^{2}$, and no nitrite was detected in the treated solution. The lowest amount of nitrate was formed with $\mathrm{Cu} / \mathrm{Zn}$ as cathode during electrolysis due to its high reduction ability. Initial $\mathrm{pH}$ range from 7 and 9 and uncontrolled temperature were favorable for electrochemical ammonia oxidation and the ammonia oxidation rates with $\mathrm{Cu} / \mathrm{Zn}$ cathode was higher than that with $\mathrm{Ti}$ and $\mathrm{Fe}$ cathode. The reduction rate increased with increasing current density in the range of $5-50 \mathrm{~mA} / \mathrm{cm}^{2}$. As ammonia could be completely removed by the simultaneous oxidation and reduction in this study, it is suitable for deep treatment of ammonia polluted water.
\end{abstract}

Keywords: Electrochemical Oxidation; Ammonia; Nitrate; $\mathrm{Cu} / \mathrm{Zn}$; Sodium Chloride

\section{Introduction}

Nowadays, around the world most of the water bodies are polluted and some are heavily polluted. Among the water pollution, ammonia contamination of water bodies is a widespread environment problem. Ammonia containing wastewaters will cause eutrophication and fish kills which disrupt aquatic ecosystems in a severe manner [1-3]. Therefore, aim to reduce consumption and improve treatment method efficiency for water and wastewater should be highlighted as a main public concern in the future [4-6]. Usually, two main groups of treatment processes, physicochemical and biological treatment methods, were employed for ammonia removal, which are biological process, air stripping, ion exchange, and breakpoint chlorination. Although air stripping and ion exchange are widely used, as no destruction of the contaminant, it needs to be further treated. Breakpoint chlorination demands a large amount of chlorine and relatively low efficiency. Biological method is effective with the addition of carbon sources, large land areas and significantly impaired by low temperature in winter [7]. As electrochemical method has the advantage of high treatment efficiency, no sludge production, small area occupied by the plant and relatively low investment costs, a large number of researchers has focused on it recently.

"Corresponding author.
In general, ammonia can be oxidized electrochemically into nitrogen gas, nitrate, or nitrite by direct or indirect oxidation processes.

So far several metals have been investigated [8-10], such as $\mathrm{Ti} / \mathrm{IrO}_{2}-\mathrm{Pt}$, Lead Dioxide and $\mathrm{BDD}-\mathrm{TiO}_{2}$ Anode. It was shown that ammonia is effectively removed from solution while active chlorine was electrogenerated on a $\mathrm{Ti} / \mathrm{PtOx}-\mathrm{IrO}_{2}$ electrode. Nitrogen gaseous is postulated to be the main by-product of ammonia electrolysis [11]. Direct (non-mediated) electrochemical oxidation of ammonia on boron-doped diamond (BDD) electrode occurred mainly when $\mathrm{pH}$ value above 8.0 by free ammonia $\left(\mathrm{NH}_{3}\right)$ oxidation. Otherwise when $\mathrm{pH}$ value was below 8.0, oxidation of ammonia was mediated by active free chlorine. Thus, active chlorine effectively removes ammonia from an acidic solution, while the formation of by-products such as chlorate and possibly perchlorate is minimized [12]. Electro-oxidation of ammonia process inhibited the oxygen evolution reaction (OER) as ammonia oxidation products was absorbed on the BDD surface. Nitrogen, nitrous oxide, and nitrogen dioxide were detected as the ammonia oxidation products. Nitrogen gaseous was the main product of the oxidation [13]. The electro-activity of the Pt and DSA (Dimensionally Stable Anode) electrodes and $\mathrm{Ni}$ were confirmed by cyclic voltammogram at $\mathrm{pH} 7.0$ and $\mathrm{pH} 9.4$. An anodic polarization showed the electro-activity of graphite. Anodized 
Al electrodes showed no electro-oxidation activity. The electrochemical activity of $\mathrm{Ni}$ electrodes demonstrated this material for ammonia and ammonium ion electrooxidation at both $\mathrm{pH}$ values investigated [14]. A disadvantage of the platinum electrode is that their activities are disrupted by the formation of a platinum oxide (PtO) layer at the cathodic electrode surface [15]. Combination of graphite and titanium dioxide electrode considerably enhance the removal efficiency for the present study [16]. In general, the anode is believed to be the key factor that affects the ammonia removal, and nitrate and nitrite were found to be the side products during the electrochemical ammonia removal. With our best knowledge, most researchers focused on the effect of anode on ammonia oxidation, seldom has focused on the cathode, which may play an important role on the side products generated during electrochemical ammonia oxidation [17]. On the other hand, researchers found that the cathodes such as $\mathrm{Cu} / \mathrm{Zn}$ and $\mathrm{Fe}$ had high efficiency on nitrate and nitrite removal [18]. Therefore, it is possible to decrease the production of side products by employing cathode with high nitrate and nitrite reduction ability.

In this work, in order to completely electrochemical oxidize ammonia and reduce the formation of by-products, cathodic reduction of by-products and anodic oxidation of ammonia were investigated in an undivided cell. As only a few researchers focus on the effect of Fe, $\mathrm{Cu} / \mathrm{Zn}$ cathode on ammonia removal, and previous research had suggested that cathode has significant effect on reduction product. The effect of ammonia removal by varies cathodes $(\mathrm{Fe}, \mathrm{Cu} / \mathrm{Zn}, \mathrm{Ti})$ was investigated, with aim to completely destroy ammonia, to reduce the formation of by-products and enhance current efficiency simultaneously. On the other hand, $\mathrm{Ti} / \mathrm{RuO}_{2}-\mathrm{Pt}$ anode was reported to have good oxidation ability, therefore it is employed as anode in the present study.

\section{Materials and Methods}

\subsection{Electrochemical Apparatus}

Batch experiments were conducted in an apparatus at room temperature (about $23.0^{\circ} \mathrm{C}-26.0^{\circ} \mathrm{C}$ ). A continuous electrochemical cell was designed in our lab with a net working volume of $400.0 \mathrm{ml}$. The $400-\mathrm{mL}$ electrolysis cell was made of acryl plates with four outer spots for the electrodes assembled. Three metal plates include $\mathrm{Cu} / \mathrm{Zn}$ $(\mathrm{Cu}: 62.2 \mathrm{wt} \%$; Zn: $37.8 \mathrm{wt} \%)$, Ti and $\mathrm{Fe}$ plate of 75.0 $\mathrm{cm}^{2}(15.0 \mathrm{~cm} \times 5.0 \mathrm{~cm})$ were used as the cathode moreover $\mathrm{Ti} / \mathrm{RuO}_{2}-\mathrm{Pt}$ (TohoTech company, Japan) was used as the anode with the same area with a distance of 8.0 $\mathrm{mm}$ between the two electrodes respectively. A DC power with a voltage range of $0-50.0 \mathrm{~V}$ and a current range of 0 - 5.0 A was employed as power supply. Test synthetic ammonia solutions were prepared using $\left(\mathrm{NH}_{4}\right)_{2} \mathrm{SO}_{4}$ and distilled water to give a final concentration of 100.0 $\mathrm{mg} \cdot \mathrm{L}^{-1}$, with no $\mathrm{Cl}^{-}$. In the solution, free ammonia concentration is only $0.0198 \mathrm{mg} \cdot \mathrm{L}^{-1}$. The $\mathrm{NaCl}$ dosage of 0 $\mathrm{g} \cdot \mathrm{L}^{-1}, 0.5 \mathrm{~g} \cdot \mathrm{L}^{-1}, 1.0 \mathrm{~g} \cdot \mathrm{L}^{-1}, 2.0 \mathrm{~g} \cdot \mathrm{L}^{-1}(\mathrm{w} / \mathrm{v})$ were added into the synthetic ammonia solutions to investigate the effect of influencing factors (sodium chloride dosage, current density, temperature, initial $\mathrm{pH}$ value; respectively). While current density was varied between 5.0 $\mathrm{mA} / \mathrm{cm}^{2}$ and $50.0 \mathrm{~mA} / \mathrm{cm}^{2}$. The initial $\mathrm{pH}$ value was adjusted from 3.0 to 11.0 by $\mathrm{NaOH}(0.1 \mathrm{M})$ or $\mathrm{H}_{2} \mathrm{SO}_{4}(0.1$ M). $0.50 \mathrm{~g} \cdot \mathrm{L}^{-1} \mathrm{Na}_{2} \mathrm{SO}_{4}$ was added in all solution as supporting electrolyte. At different intervals, $1.5 \mathrm{~mL}$ of sample was drawn from the electrochemical cell for analysis. The electrolysis was ceased when either $90.0 \%$ of initial ammonia was converted or $2 \mathrm{~h}$ elapsed.

\subsection{Analysis}

All analyses were done according to standard methods (APHA, 1998). The determination of ammonia was performed by Ion meter (Ti 9001, Toyo chemical laboratories Co., Ltd.). Nitrate was determined by standard colorimetric method using spectrophotometer (DR/4000U Spectrophotometer, USA), and nitrite was analyzed by ion chromatography (Yokogawa IC7000, AS9-HC column).

\section{Results and Discussion}

\subsection{Influence of $\mathrm{NaCl}$ Dosages}

In the present experiment, as $\mathrm{NaCl}$ plays an important role on not only the ammonia oxidation rate, but also the formation of the by-product nitrate, the performance of electrochemical ammonia oxidation with different $\mathrm{NaCl}$ dosages was investigated.

Figures 1 and 2 were concentrations of ammonia-N and nitrate- $\mathrm{N}$ with respect of time.

It confirmed that without $\mathrm{NaCl}$ addition, ammonia removal rate showed almost same results with different cathode. Opposite the different amounts of nitrate formation during the electrochemical oxidation of ammonia can be attributed to the different of the cathodes in the absence of $\mathrm{NaCl}$, in which $\mathrm{Cu} / \mathrm{Zn}$ cathode showed lowest by-product formation. Cupro-zinc materials were wellknown as their good corrosion resistance. Moreover, zinc has a good electroactivity while copper displays a good activity of electroreduction. As a result, a synergistic effect of alloying $\mathrm{Zn}$ with $\mathrm{Cu}$ could be expected.

From the observed results, it can be concluded that $\mathrm{Cu} / \mathrm{Zn}$ cathode is more suitable for ammonia removal than $\mathrm{Ti}$ and $\mathrm{Fe}$ cathodes in the absence of $\mathrm{NaCl}$ because of its high selectivity for ammonia oxidation to nitrogen gas. The effect of varying $\mathrm{Cl}^{-}$concentration on ammonia-N and nitrate- $\mathrm{N}$ removal was also shown. It can be concluded that these three cathodes showed almost same 

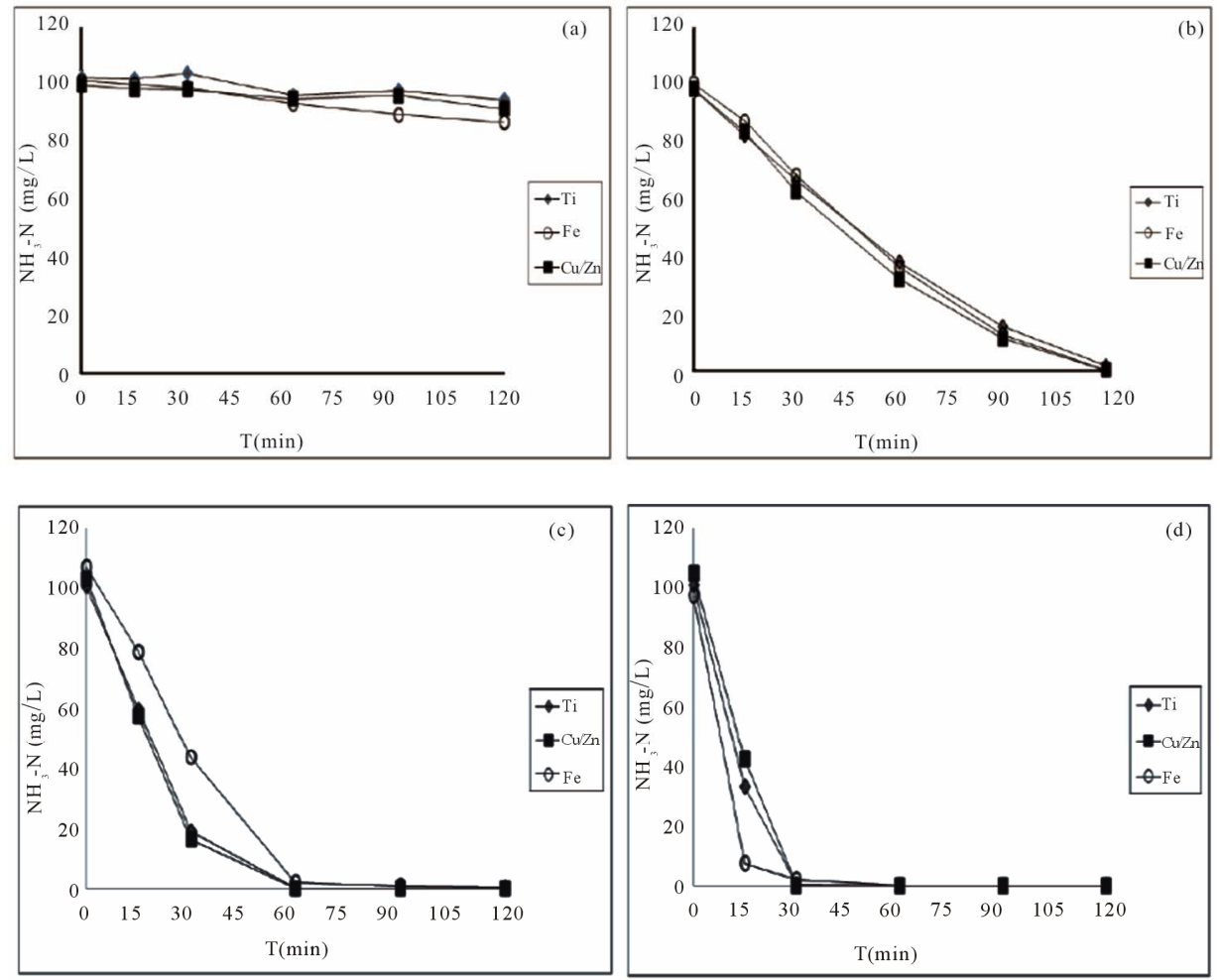

Figure 1. Concentration of ammonia with respect of time. Anode: $\mathrm{Ti} / \mathrm{RuO} \mathrm{O}_{2}-\mathrm{Pt}$, cathode: Ti, Fe, $\mathrm{Cu} / \mathrm{Zn}, 30 \mathrm{~mA} / \mathrm{cm}^{2}, 0$ (a), 0.5 (b), 1.0 (c), 2.0 (d) g/l NaCl respectively.
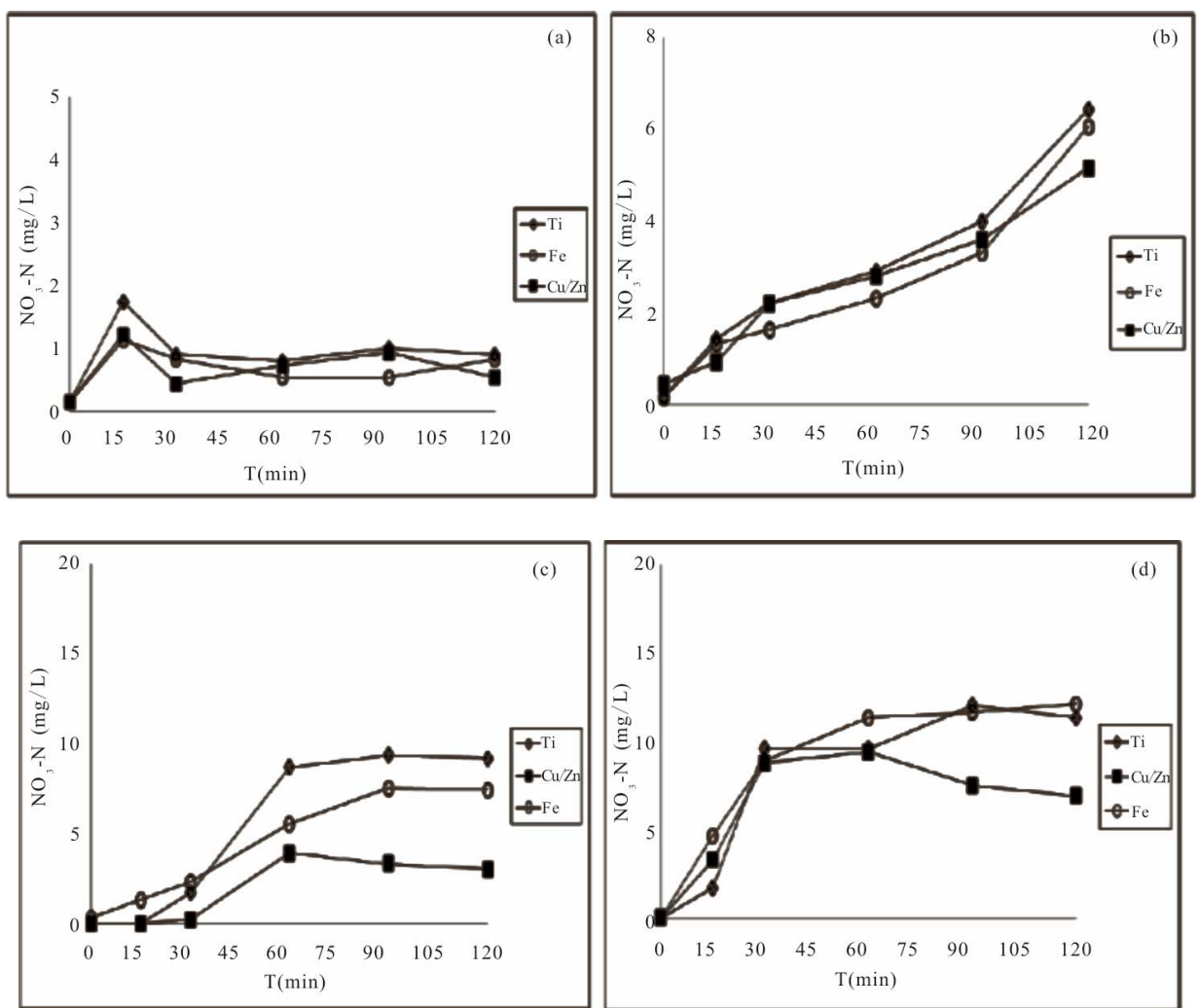

Figure 2. Concentration of nitrate with respect of time. Anode: $\mathrm{Ti} / \mathrm{RuO}_{2}-\mathrm{Pt}$, cathode: $\mathrm{Ti}, \mathrm{Fe}, \mathrm{Cu} / \mathrm{Zn}, 30 \mathrm{~mA} / \mathrm{cm}^{2}, 0$ (a), 0.5 (b), 1.0 (c), 2.0 (d) g/l NaCl respectively. 
results on ammonia removal with the same dosage of $\mathrm{NaCl}$. In the presence of $0.5 \mathrm{~g} / \mathrm{L} \mathrm{NaCl}$ after $120 \mathrm{~min}$ electrolysis, ammonia- $\mathrm{N}$ decreased from $100 \mathrm{mg} / \mathrm{L}$ to 1.8 $\mathrm{mg} / \mathrm{L}, 0.4 \mathrm{mg} / \mathrm{L}$ and $0.4 \mathrm{mg} / \mathrm{L}$ respectively with $\mathrm{Ti}$, $\mathrm{Cu} / \mathrm{Zn}$ and $\mathrm{Fe}$ cathodes.

It is clear that the ammonia-N was significantly decreased compared with that in the absence of $\mathrm{NaCl}$, which proved the key role of indirect oxidation during electrochemical oxidation of ammonia [19]. Meanwhile nitrate- $\mathrm{N}$ increased from 0 to $6.4 \mathrm{mg} / \mathrm{L}, 5.2 \mathrm{mg} / \mathrm{L}$ and 6.0 $\mathrm{mg} / \mathrm{L}$ respectively. In the presence of $1.0 \mathrm{~g} / \mathrm{L}$ and $2.0 \mathrm{~g} / \mathrm{L}$ $\mathrm{NaCl}$, the ammonia decreased sharply, which conform that in the presence of chloride ions, hypochlorite ions will be formed and then oxidize the ammonia and byproduct presumably to nitrogen gas [20] as listed in Equations (1)-(5).

$$
\begin{aligned}
& 2 \mathrm{Cl}^{-} \rightarrow \mathrm{Cl}_{2}+2 \mathrm{e}^{-} \\
& \mathrm{Cl}_{2}+\mathrm{H}_{2} \mathrm{O} \rightarrow \mathrm{HClO}+\mathrm{H}^{+}+\mathrm{Cl}^{-} \\
& \mathrm{HClO} \rightarrow \mathrm{ClO}^{-}+\mathrm{H}^{+} \\
& \mathrm{NH}_{4}^{+}+\mathrm{HClO} \rightarrow \mathrm{N}_{2}+\mathrm{H}_{2} \mathrm{O}+\mathrm{H}^{+}+\mathrm{Cl}^{-} \\
& \mathrm{NH}_{4}^{+}+\mathrm{HClO} \rightarrow \mathrm{NO}_{3}^{-}+\mathrm{H}_{2} \mathrm{O}+\mathrm{Cl}^{-}
\end{aligned}
$$

None nitrite was detected throughout the experiment. Overall, about $90 \%$ of removed ammonia was changed into $\mathrm{N}_{2}$ gas with $\mathrm{NaCl}$ addition, which was similar with other report [21].

The production of $\mathrm{N}_{2}$ could be calculated as equal to the loss of $\mathrm{N}$ element according to the $\mathrm{N}$ conservation law [22]. Simultaneously, intermediate nitrate ions were formed in the water.

On the contrary the by-product formation had different results. The nitrate formation could come from not only the indirect oxidation of ammonia by $\mathrm{HClO}$ but also by hydroxyl radicals. The by-product formation generated by $\mathrm{Ti}$ and $\mathrm{Fe}$ was increased during electrolysis while using $\mathrm{Cu} / \mathrm{Zn}$ cathode, it increased for the first period of time and then decreased finally. The reason why the $\mathrm{NO}_{3}^{-}$concentration was the lowest with $\mathrm{Cu} / \mathrm{Zn}$ cathode was that because of its high reduction ability. Ma'cova' and Bouzek found that brass containing $\mathrm{Zn}$ higher than $35 \mathrm{wt} \%$, lower than $41 \mathrm{wt} \%$ will significantly influence the kinetic of current density, and higher electrocatalytic activity of $\mathrm{Cu} / \mathrm{Zn}$ alloy containing $\mathrm{Zn}$ of $35-41 \mathrm{wt} \%$ than both $\mathrm{Cu}$ and $\mathrm{Zn}$ was observed

It can be concluded that ammonia oxidation rate was increased with the increasing dosage of $\mathrm{NaCl}$, while nitrate formation was different with various cathodes, which suggested that with an appropriate cathode and an appropriate concentration of chloride ion in the ammonia solution during the electrolysis process, the ammonia can be efficiently removed and relatively low amount of by- products will be formed. Therefore, the electrochemical process in the presence of chlorides showed a higher capacity and selectivity in ammonia transformation into nitrogen gas [22]. It could be considered that an optimum $\mathrm{NaCl}$ addition in the present experiment is $1.0 \mathrm{~g} / \mathrm{L}$, the best cathode is $\mathrm{Cu} / \mathrm{Zn}$ cathode. As the combination of $\mathrm{Ti} / \mathrm{RuO}_{2}-\mathrm{Pt}$ anode and $\mathrm{Cu} / \mathrm{Zn}$ cathode showed a good performance for ammonia oxidation, the influence of several parameters, such as, current density, initial $\mathrm{pH}$, temperatures were studied.

\subsection{Influence of Current Density}

The rate of an electrochemical reaction is measured as current density, current per area. As current density controls the reaction rate that may be the most frequently referred term in an electrochemical process [23]. In this work, current densities ranged from $5.0 \mathrm{~mA} / \mathrm{cm}^{2}$ as it is the minimum required to achieve an effective oxidation of ammonia. The effect of applied current density on ammonia removal during the electrochemical reduction was shown in Figure 3(a).

As seen, the ammonia oxidation rate almost increased with increasing current density in the range of 5.0 $\mathrm{mA} / \mathrm{cm}^{2}$ to $50.0 \mathrm{~mA} / \mathrm{cm}^{2}$. Ammonia-N decreased from $100.0 \mathrm{mg} / \mathrm{L}$ to $66.9 \mathrm{mg} / \mathrm{L}, 28.9 \mathrm{mg} / \mathrm{L}, 0.9 \mathrm{mg} / \mathrm{L}, 0 \mathrm{mg} / \mathrm{L}$ in $120 \mathrm{~min}$ respectively. That conformed to the previous report, an increase in current density improves ammonia-N treatment efficiencies under the same charge loading. The possible reason is that the increased current density during electrochemical oxidation could enhance chlorine generation, which was responsible for subsequent removal of pollutions [19].

Figure 3(b) showed the variation of nitrate- $\mathrm{N}$ during electrolysis at different current densities. The final concentration of nitrate- $\mathrm{N}$ decreased with the increasing of current density. The nitrate- $\mathrm{N}$ increased from 0 to 1.8 $\mathrm{mg} / \mathrm{L}, 1.7 \mathrm{mg} / \mathrm{L}, 2.4 \mathrm{mg} / \mathrm{L}, 3.0 \mathrm{mg} / \mathrm{L}, 0.7 \mathrm{mg} / \mathrm{L}$ and 0.8 $\mathrm{mg} / \mathrm{L}$ in $120 \mathrm{~min}$ respectively. As it has been reported that the ammonia oxidation rate was linearly in accordance with current density, which is in agreement with the present experiments [24]. At lower current density, less amount of hypochlorite acid was produced, which was not enough to oxidize all of the ammonia. Therefore, in the present experiments, in order to remove all of the ammonia, the current density should higher than 30.0 $\mathrm{mA} / \mathrm{cm}^{2}$.

\subsection{Influence of Initial $\mathbf{p H}$}

The effect of different initial $\mathrm{pH}$ values on ammonia removal and by-product formation was shown in Figure 4. It can be seen that the tendencies of reduction of ammonia were similar both at initial $\mathrm{pH} 3.0,5.0$ and 7.0. The ammonia-N decreased from $100.0 \mathrm{mg} / \mathrm{L}$ to $3.0 \mathrm{mg} / \mathrm{L}, 0.8$ 

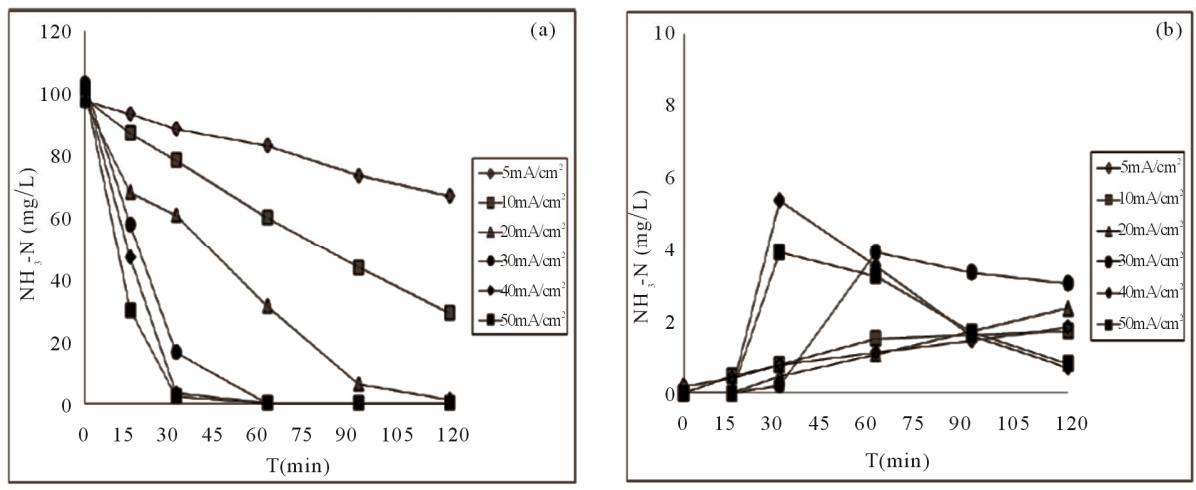

Figure 3. Concentration of ammonia and nitrate with respect of time at different current density. Anode: $\mathrm{Ti} / \mathrm{RuO} \mathrm{O}_{2}-\mathrm{Pt}$, cathode: $\mathrm{Cu} / \mathrm{Zn}, 1.0 \mathrm{~g} / \mathrm{l} \mathrm{NaCl}$.
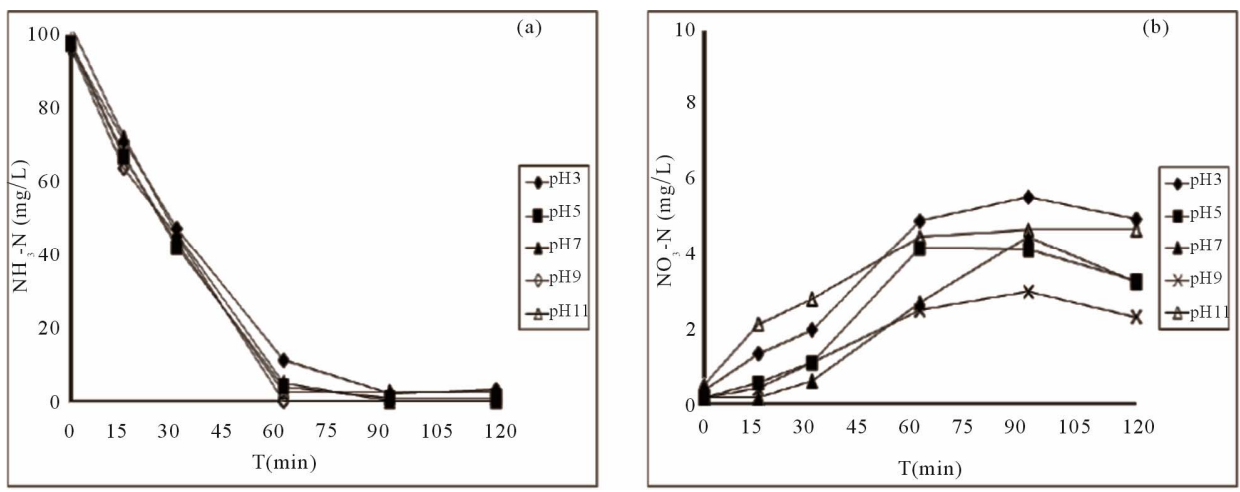

Figure 4. Concentration of ammonia and nitrate with respect of time at different initial $\mathrm{pH}$. Anode: $\mathrm{Ti} / \mathrm{RuO}_{2}-\mathrm{Pt}$, cathode: $\mathrm{Cu} / \mathrm{Zn}, 1.0 \mathrm{~g} / \mathrm{l} \mathrm{NaCl}, 30 \mathrm{~mA} / \mathrm{cm}^{2}$.

$\mathrm{mg} / \mathrm{L}$ and $0 \mathrm{mg} / \mathrm{L}$ in $120 \mathrm{~min}$, respectively, while at initial $\mathrm{pH} 9.0$ and 11.0, the ammonia-N decreased from $100.0 \mathrm{mg} / \mathrm{L}$ to $0 \mathrm{mg} / \mathrm{L}$ in only $60 \mathrm{~min}$. As free ammonia concentration is about 35.95 and $98.25 \mathrm{mg} / \mathrm{L}$ respectively, according to previous research, solubility of free ammonia in water at room temperature is about $3 \mathrm{~mol} / \mathrm{kg}$ [25], it can be considered that electrochemical method was contributed to ammonia removal mainly. The finial concentration of by-product with initial $\mathrm{pH} 9$ was the lowest throughout the experiment. It can be conclude from the present experiment that the optimum initial $\mathrm{pH}$ range for ammonia removal was $\mathrm{pH} 7-\mathrm{pH}$ 9. This result is agree with Lin and $\mathrm{Wu}$ [16], but different from Vlyssides et al. [26]. Similar results were also obtained by Chiang et al. [27] and $\mathrm{Li}$ and Liu [28]. The reason for that is because of the formation of $\mathrm{HOCl}$ was affected disadvantageously by low pH, as shown in Equation (2). Oppositely, in strongly alkaline conditions, $\mathrm{HOCl}$, a strongly oxidation agent to ammonia, is transformed into $\mathrm{ClO}_{3}^{-}$, which has lower oxidability than $\mathrm{HOCl}$ [29]. Therefore, strongly alkaline conditions decrease ammonia removal efficiency. Therefore, in this study initial $\mathrm{pH}$ ranges from 7 to 9 was suggested for ammonia removal due to the presence of high concentration of $\mathrm{HOCl}$.

\subsection{Influence of Temperature}

Figure 5 showed the variation of ammonia-N and nitrate-N during electrolysis at different temperatures. As it is difficult to maintenance high temperature throughout experiments, the temperatures was only set to be at uncontrolled and at $25^{\circ} \mathrm{C}$. Under the condition of uncontrolled temperature, the temperature of the treated solution increased from $25.0^{\circ} \mathrm{C}$ to $40.3^{\circ} \mathrm{C}$ after 120 min electrolysis. Meanwhile all of the ammonia was destroyed in 60 mins. Under the controlled temperature $\left(25^{\circ} \mathrm{C}\right)$ ammonia oxidation was a little slower. This was mainly due to different $\mathrm{pH}$ changes in the electrolyte at different temperatures during the electrolysis (date did not showed). The $\mathrm{pH}$ change was caused by the various reactions during ammonia oxidation process (Equations (1)-(5)). As previously mentioned, increasing $\mathrm{pH}$ was favorable for ammonia oxidation; moreover, increasing temperature could increase the rate of diffusion and the strength of adsorption. Consequently, the ammonia oxidation rate increased when the temperature was increased from $25.0^{\circ} \mathrm{C}$ to $40.3^{\circ} \mathrm{C}$.

In addition, according to previous study, ammonia in aqueous solution can exist in two forms: un-ionized form $\left(\mathrm{NH}_{3}\right)$ and/or ionized form $\left(\mathrm{NH}_{4}^{+}\right)$[30]. Compare these 

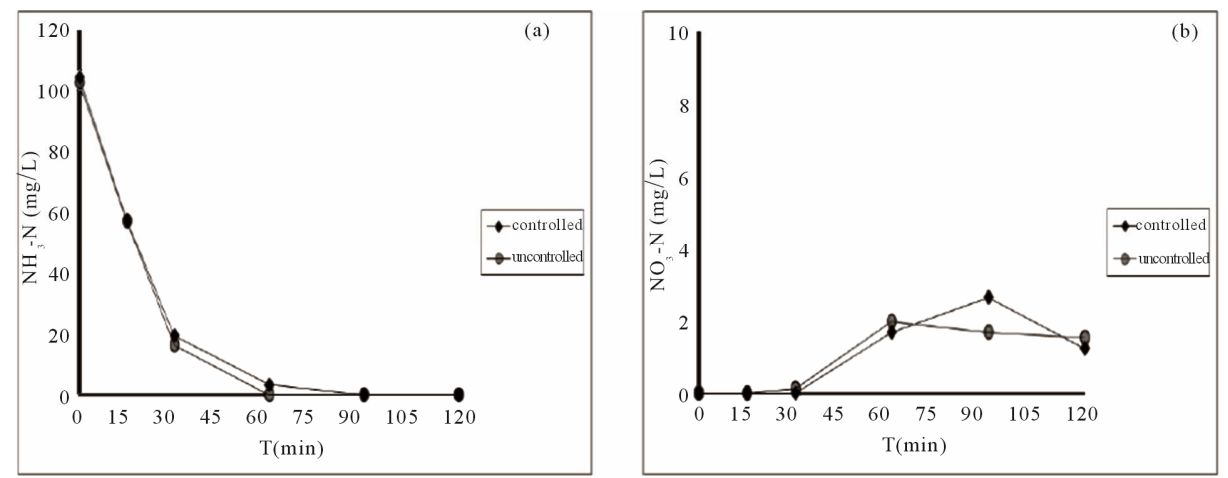

Figure 5. Concentration of ammonia and nitrate with respect of time at different temperatures. $\mathrm{Anode}: \mathrm{Ti} / \mathrm{RuO} \mathrm{O}_{2}-\mathrm{Pt}$, cathode: $\mathrm{Cu} / \mathrm{Zn}, 1.0 \mathrm{~g} / \mathrm{l} \mathrm{NaCl}, 30 \mathrm{~mA} / \mathrm{cm}^{2}$.

two forms of ammonia, the un-ionized one is much easier to be oxidized. These two forms of ammonia established an equilibrium following the Equation (6) [16].

$$
\mathrm{NH}_{3}+\mathrm{H}_{2} \mathrm{O} \leftrightarrow \mathrm{NH}_{4}^{+}+\mathrm{OH}^{-}
$$

Under uncontrolled condition, with increasing temperature larger amount of $\mathrm{NH}_{3}$ formed subsequent oxidized on electrode, which also increased ammonia oxidation rate.

In general, increasing temperature could affect ammonia oxidation rate in several ways, the uncontrolled temperature was favorable for electrochemical oxidation of ammonia.

From above, the mechanism of ammonia electro-oxidation on $\mathrm{RuO}_{2}$ electrodes and formation of $\mathrm{N}_{2}$ as a final product was indicated, that ammonia is oxidized through several steps to various nitrogen compounds, which was accord with previous reports, as Equation (7).

$$
\begin{gathered}
\mathrm{NH}_{3} \rightarrow \mathrm{NH}_{2} \mathrm{OH}_{\text {ads }} \rightarrow \mathrm{NO}_{\mathrm{x}} \\
\downarrow \\
\mathrm{N}_{2}
\end{gathered}
$$

\section{Conclusions}

In order to complete electrochemical oxidize of ammonia and reduce the formation of by-products, cathodic reduction of by-products, and anodic oxidation of ammonia were investigated in an undivided cell using $\mathrm{Ti} / \mathrm{RuO}_{2}-\mathrm{Pt}$ plate as anode and three plates as cathode for treatment of the synthetic ammonia solution. It can be concluded: 1) the ammonia- $\mathrm{N}$ decrease from $100.0 \mathrm{mg} / \mathrm{L}$ to $0 \mathrm{mg} / \mathrm{L}$ in the presence of $1.0 \mathrm{~g} / \mathrm{L} \mathrm{NaCl}$ after 120 min electrolysis at the current density of $30 \mathrm{~mA} / \mathrm{cm}^{2}$ with $\mathrm{Cu} / \mathrm{Zn}$ cathode and $\mathrm{Ti} / \mathrm{RuO}_{2}-\mathrm{Pt}$ anode. Throughout experiment none nitrite was detected in the treated solution; 2) Initial $\mathrm{pH}$ range from 7 and 9 was favorable for electrochemical ammonia oxidation; 3 ) the ammonia oxidation rates with $\mathrm{Cu} / \mathrm{Zn}$ cathode was higher than that with $\mathrm{Ti}$ and $\mathrm{Fe}$ cathode. The nitrate formed during electrolysis with $\mathrm{Cu} / \mathrm{Zn}$ was the lowest than that with other cathodes. The reason why the nitrate- $\mathrm{N}$ concentration was the lowest with $\mathrm{Cu} / \mathrm{Zn}$ cathode was that because of its high reduction ability; and 4) as increasing temperature could affect ammonia oxidation rate in several ways, the uncontrolled temperature was favorable for electrochemical oxidation of ammonia.

In the present study, the ammonia was removed completely by electrochemical approach using $\mathrm{Cu} / \mathrm{Zn}$ cathode and $\mathrm{Ti} / \mathrm{RuO}_{2}-\mathrm{Pt}$ anode with the addition of $\mathrm{NaCl}$, it is a worthy method for treatment of ammonia polluted water.

\section{Acknowledgements}

This work was supported by Grant-in-Aid for Research Activity Start-up 22880007 from Japan Society for the Promotion of Science (JSPS).

\section{REFERENCES}

[1] G. Tchobanoglous, F. L. B. H. D. Stensel and Metcalf \& Eddy, "Wastewater Engineering: Treatment and Reuse," 4th Edition, McGraw-Hill, New York, 2004.

[2] T. A. Larsen, M. M. K. M. Udert and J. Lienert, "Nutrient Cycles and Resource Management: Implications for the Choice of Wastewater Treatment Technology," Water Science and Technology, Vol. 56, No. 5, 2007, pp. 229237. doi:10.2166/wst.2007.576

[3] Y. Fernández-Nava, E. Marañón, J. Soons and L. Castrillón, "Denitrification of Wastewater Containing High Nitrate and Calcium Concentrations," Bioresource Technology, Vol. 99, No. 17, 2008, pp. 7976-7981. doi:10.1016/j.biortech.2008.03.048

[4] Y. Liu, L. Li and R. Goel, "Kinetic Study of Electrolytic Ammonia Removal Using $\mathrm{Ti} / \mathrm{IrO}_{2}$ as Anode under Different Experimental Conditions," Journal of Hazardous Materials, Vol. 167, No. 1-3, 2009, pp. 959-965. doi:10.1016/i.jhazmat.2009.01.082

[5] S.-J. Park and S.-Y. Jin, "Effect of Ozone Treatment on Ammonia Removal of Activated Carbons," Journal of Colloid and Interface Science, Vol. 286, No. 1, 2005, pp. 417-419. doi:10.1016/j.jcis.2005.01.043

[6] M. Ramírez, J. M. Gómez, G. Aroca and D. Cantero, "Removal of Ammonia by Immobilized Nitrosomonas Europaea in a Biotrickling Filter Packed with Polyurethane Foam," Chemosphere, Vol. 74, No. 10, 2009, pp. 1385- 
1390. doi:10.1016/j.chemosphere.2008.11.061

[7] M. Li, C. P. Feng and Z. Y. Zhang, "Optimization of Electrochemical Ammonia Removal Using Box-Behnken Design," Journal of Electroanalytical Chemistry, Vol. 657, No. 1-2, 2011, pp. 66-73. doi:10.1016/j.jelechem.2011.03.012

[8] M. Li, C. P. Feng, Z. Y. Zhang and N. Sugiura, "Efficient Electrochemical Reduction of Nitrate to Nitrogen Using $\mathrm{Ti} / \mathrm{IrO}_{2}$-Pt Anode and Different Cathodes," Electrochimica Acta, Vol. 54, No. 20, 2009, pp. 4600-4606. doi:10.1016/j.electacta.2009.03.064

[9] G. H. Zhao, Y. G. Zhang, Y. Z. Lei, B. Y. Lv, J. X. Gao, Y. A. Zhang and D. M. Li, "Fabrication and Electrochemical Treatment Application of a Novel Lead Dioxide Anode with Superhydrophohic Surfaces, High Oxygen Evolution Potential, and Oxidation Capability," Environment Science Technology, Vol. 44, No. 5, 2010, pp. 1754-1759. doi:10.1021/es902336d

[10] J. H. Qu and X. Zhao, "Design of BDD-TiO 2 Hybrid Electrode with P-N Function for Photoelectrocatalytic Degradation of Organic Contaminants," Environment Science Technology, Vol. 42, No. 13, 2008, pp. 4934-4939. doi:10.1021/es702769p

[11] A. Kapałka, A. Katsaounis and A. Leonidova, "Ammonia Oxidation to Nitrogen Mediated by Electrogenerated Active Chlorine on Ti/PtOx-IrO ${ }_{2}$," Electrochemistry Communications, Vol. 12, No. 9, 2010, pp. 1203-1205. doi:10.1016/j.elecom.2010.06.019

[12] A. Kapałka, L. Joss and C. Comninellis, "Direct and Mediated Electrochemical Oxidation of Ammonia on Boron-Doped Diamond Electrode," Electrochemistry Communications, Vol. 12, No. 12, 2010, pp. 1714-1717. doi:10.1016/j.elecom.2010.10.004

[13] N.-L. Michels, A. Kapalka and A. A. Abd-El-Latif, "Enhanced Ammonia Oxidation on BDD Induced by Inhibition of Oxygen Evolution Reaction," Electrochemistry Communications, Vol. 12, No. 9, 2010, pp. 1199-1202. doi:10.1016/j.elecom.2010.06.018

[14] L. Candido and J. A. C. P. Gomes, "Evaluation of Anode Materials for the Electro-Oxidation of Ammonia and Ammonium Ions," Materials Chemistry and Physics, Vol. 129, No. 3, 2011, pp. 1146-1151. doi:10.1016/j.matchemphys.2011.05.080

[15] Z. Du, H. Li and T. Gu, "A State of the Art Review on Microbial Fuel Cells: A Promising Technology for WasteWater Treatment and Bioenergy," Biotechnology Advances, Vol. 25, No. 5, 2007, pp. 464-482. doi:10.1016/j.biotechadv.2007.05.004

[16] S. H. Lin and C. L. Wu, "Electrochemical Removal of Nitrite and Ammonia for Aquaculture," Water Research, Vol. 30, No. 3, 1996, pp. 715-721. doi:10.1016/0043-1354(95)00208-1

[17] M. Li, C. P. Feng and Z. Y. Zhang, "Simultaneous Reduction of Nitrate and Oxidation of By-Products Using Electrochemical Method," Journal of Hazardous Materials, Vol. 171, No. 1-3, 2009, pp. 724-730. doi:10.1016/j.jhazmat.2009.06.066

[18] M. Li, C. P. Feng and Z. Y. Zhang, "Application of an Electrochemical-Ion Exchange Reactor for Ammonia Re- moval," Electrochimica Acta, Vol. 55, No. 1, 2009, pp. 159-164. doi:10.1016/j.electacta.2009.08.027

[19] Y. Deng and J. D. Englehardt, "Electrochemical Oxidation for Landfill Leachate Treatment," Waste Management, Vol. 27, No. 3, 2007, pp. 380-388. doi:10.1016/j.wasman.2006.02.004

[20] M. Li, C. P. Feng and Z. Y. Zhang, "Electrochemical Reduction of Nitrate Using Various Anodes and a $\mathrm{Cu} / \mathrm{Zn}$ Cathode," Electrochemistry Communications, Vol. 11, No. 10, 2009, pp. 1853-1856. doi:10.1016/j.elecom.2009.08.001

[21] K.-W. Kim, “The Electrolytic Decomposition Mechanism of Ammonia to Nitrogen at an $\mathrm{IrO}_{2}$ Anode," Electrochimica Acta, Vol. 50, No. 22, 2005, pp. 4356-4364. doi:10.1016/j.electacta.2005.01.046

[22] S. Xiao, J. Qu and X. Zhao, "Electrochemical Process Combined with UV Light Irradiation for Synergistic Degradation of Ammonia in Chloride-Containing Solutions," Water Research, Vol. 43, No. 5, 2009, pp. 1432-1440. doi:10.1016/j.watres.2008.12.023

[23] G. Chen, "Electrochemical Technologies in Wastewater Treatment," Separation and Purification Technology, Vol. 38, No. 1, 2004, pp. 11-41. doi:10.1016/j.seppur.2003.10.006

[24] Y. Vanlangendonck, D. Corbisier and A. Van Lierde, "Influence of Operating Conditions on the Ammonia Electro-Oxidation Rate in Wastewaters from Power Plants (ELONITA $^{\mathrm{TM}}$ technique)," Water Research, Vol. 39, No. 13, 2005, pp. 3028-3034. doi:10.1016/j.watres.2005.05.013

[25] B. Rumpf, A. P.-S. Kamps, R. Sing and G. Maurer, "Simultaneous Solubility of Ammonia and Hydrogen Sulfide in Water at Temperatures from $313 \mathrm{~K}$ to $393 \mathrm{~K}$," Fluid Phase Equilibria, Vol. 158-160, 1999, pp. 923-932. doi:10.1016/S0378-3812(99)00110-7

[26] A. G. Vlyssides, "Electrochemical Treatment in Relation to $\mathrm{pH}$ of Domestic Wastewater Using Ti/Pt Electrodes," Journal of Hazardous Materials, Vol. 95, No. 1-2, 2002, pp. 215-226. doi:10.1016/S0304-3894(02)00143-7

[27] L.-C. Chiang, J.-E. Chang and T.-C. Wen, "Indirect Oxidation Effect in Electrochemical Oxidation Treatment of Landfill Leachate," Water Research, Vol. 29, No. 2, 1995 , pp. 671-678. doi:10.1016/0043-1354(94)00146-X

[28] L. Li and Y. Liu, "Ammonia Removal in Electrochemical Oxidation: Mechanism and Pseudo-Kinetics," Journal of Hazardous Materials, Vol. 161, No. 2-3, 2009, pp. 10101016. doi:10.1016/j.jhazmat.2008.04.047

[29] A. H. Mahvi, "Performance Evaluation of a Continuous Bipolar Electrocoagulation/Electrooxidation-Electroflotation (ECEO-EF) Reactor Designed for Simultaneous Removal of Ammonia and Phosphate from Wastewater Effluent," Journal of Hazardous Materials, Vol. 192, No. 3, 2011, pp. 1267-1274. doi:10.1016/j.jhazmat.2011.06.041

[30] S. Körner, S. K. Das and S. Veenstra, "The Effect of pH Variation at the Ammonium/Ammonia Equilibrium in Wastewater and Its Toxicity to Lemna Gibba," Aquatic Botany, Vol. 71, No. 1, 2001, pp. 71-78. doi:10.1016/S0304-3770(01)00158-9 